УДК 902/904

https://doi.org/10.24852/2587-6112.2021.2.250.260

\title{
НОВЫЕ МАТЕРИАЛЫ С СЕЛИЩА ЗИНИНО-1
}

\section{(C) 2021 г. А.С. Проценко, Р.М. Сатаев}

Селище Зинино-1 - сезонная стоянка убаларского культурного типа кара-абызской археологической культуры. В статье обсуждаются результаты исследования керамического и археозоологического материала из раскопок памятника. Целью исследования являлось оценка степени влияния убаларского населения на хозяйственный уклад носителей кара-абызской культуры в целом. Коллекция керамического материала ярко иллюстрирует «симбиоз» населения Южного Приуралья на рубеже эр. Анализ примесей к формовочной массе сосудов позволило установить преобладание керамики убаларского типа, что подтверждает культурную атрибуцию селища. Убаларская керамика выделяется по плотной фактуре теста и высокому содержанию в нем песка. Среди индивидуальных находок присутствуют четыре фрагмента терочных плит, но их назначение остается неясным. Предположительно они не использовались при приготовлении пищи. Археозоологический материал немногочисленный. Концентрация костей в культурном слое невысокая, только в первом горизонте остатки животных встречены во всех квадратах. Несмотря на это, здесь были выявлены остатки животных, происходящие от пяти домашних и двух диких видов. По количеству костей лидирует крупный рогатый скот. Пересчет количества костей на объем мясной продукции дает основание говорить, что основой мясного рациона жителей селища являлась говядина и конина. В целом, рассмотренный материал не дает оснований говорить, что приход убаларского населения как-то существенно повлиял на хозяйственный уклад кара-абызских племен.

Ключевые слова: археология, ранний железный век, кара-абызская культура, убаларский тип, Южное Приуралье.

\section{NEW MATERIALS FROM ZININO-1 ANCIENT VILLAGE}

\section{A.S. Protsenko, R.M. Sataev}

Zinino-1 ancient village is a seasonal site of the Ubalar cultural type of the Kara-Abyz archaeological culture. The paper discusses the results of a study of ceramic and zooarchaeological material from the excavations carried out at the site. The purpose of the study was to assess the degree of influence of the Ubalar population on the economic structure of the carriers of the Kara-Abyz culture in general. The collection of ceramic material vividly illustrates the "symbiosis" of the population of the Southern Urals at the turn of the historic periods. An analysis of impurities to the molding mass of the vessels made it possible to establish the predominance of ceramics of the Ubalar type, which substantiates the cultural attribution of the ancient village. Ubalar ceramics is distinguished by the dense texture of the dough and the high content of sand therein. The individual finds include four fragments of grating slabs, but their purpose remains unclear. Presumably, they were not used in food preparation. The zooarchaeological material is scarce. The concentration of bones in the cultural layer is low; only in the first horizon contained animal remains in all its sections. Despite this, animal remains have been identified at the site, originating from five domestic and two wild species. Cattle is predominant in terms of the number of bones. A recalculation of the number of bones for the volume of meat products gives ground to say that the basis of the meat ration of the village's inhabitants was beef and horse meat. In general, the reviewed material does not give reason to say that the arrival of the Ubalar population had a significant influence the economic structure of the Kara-Abyz tribes.

Keywords: archaeology, Early Iron Age, Kara-Abyz culture, Ubalar type, Southern Cis-Urals.

Селище Зинино-1 выявлено в 2008 г. сотрудниками Центра охраны памятников Министерства культуры РБ И.И. Бахшиевым и Т.Р. Сатаровым, в 2012 г. площадка дополнительно осматривалась экспедицией научноисследовательского центра «Наследие» (рук. Н.С. Савельев). Результаты исследования опубликованы исследователями (Бахшиев, Савельев, 2013). В 2016 г. археологической экспедицией БГПУ им. Акмуллы под руковод- ством автора исследование памятника было продолжено.

Селище расположено в 7 км к юго-востоку от южной оконечности Уфимского полуострова, в широкой пойме правого берега р. Белой, недалеко от впадения в нее р. Уфы (рис. 1), в 1,5 км к западу - северо-западу от д. Зинино, в 0,6 км к югу от автодороги Самаpa - Уфа - Челябинск (М-5 «Урал») и в 0,75 км к северу от железной дороги Дема - Игли- 
но. Русло р. Белой находится в 4 км к западу, русло р. Уфы - в 5 км к северу. Селище находится на краю пойменной террасы (высокой поймы), приурочено к мысовидной оконечности пологой пойменной гривы. С юга площадка ограничена широким логом, в приустьевой части которого находятся 3 крупных провала, имеющих, вероятно, родниковое происхождение. Высота площадки памятника над уровнем р. Белой составляет около 9 м, над уровнем заболоченной и заросшей лесом поймы (89 мБС) - 6 м. Высота гривы от уровня пойменной террасы составляет 1,5-2 м (Бахшиев, Савельев, 2013, с. 105-106). По совокупности анализа полученных артефактов селище датировано авторами исследований эпохами раннего железного века (курмантауская и кара-абызская культуры) и раннего Средневековья (бахмутинская культура).

Необходимо отметить высокий историкокультурный потенциал территории, где расположено селище Зинино-1. В 7-9 км к востоку от памятника расположен комплекс памятников эпохи раннего железного века с. Акбердино Иглинского района Республики Башкортостан. За последние несколько лет были выявлены новые поселенческие памятники (сезонные селища) в районе данной террито- рии. В одной из работ В.И. Лясович вводит в научный оборот полученные материалы (Лясович, 2020)ํ. Анализ полученных материалов позволил ему выделить сезонную систему освоения человеком одного из участков правого берега р. Белой в раннем железном веке. В данном случае сезонная система освоения, по мнению автора, - это хозяйственное использование населением раннего железного века овражно-балочного комплекса, на котором располагалось и крупное городище (Акбердинское II). Предполагается, что благоприятные географические условия правого берега р. Белой в эпоху раннего железа способствовали концентрации поселенческих объектов в одном месте и позволяли успешно заниматься хозяйством (Лясович, 2020, с. 50).

В 2016 г. в центральной части площадки памятника был заложен раскоп, который представлял собой вытянутый с севера на юг прямоугольник общей площадью $24 \mathrm{~m}^{2}$. Раскоп был разбит на квадраты размерами $2 \times 2$ м (кв. 1-5) и $1 \times 2$ м (кв. 6-7), с оставлением одной бровки по линии запад - восток.

К моменту раскопок площадка памятника была хорошо задернована и не имела видимых повреждений (необходимо отметить, что до 2012 г. территория памятника подвер-

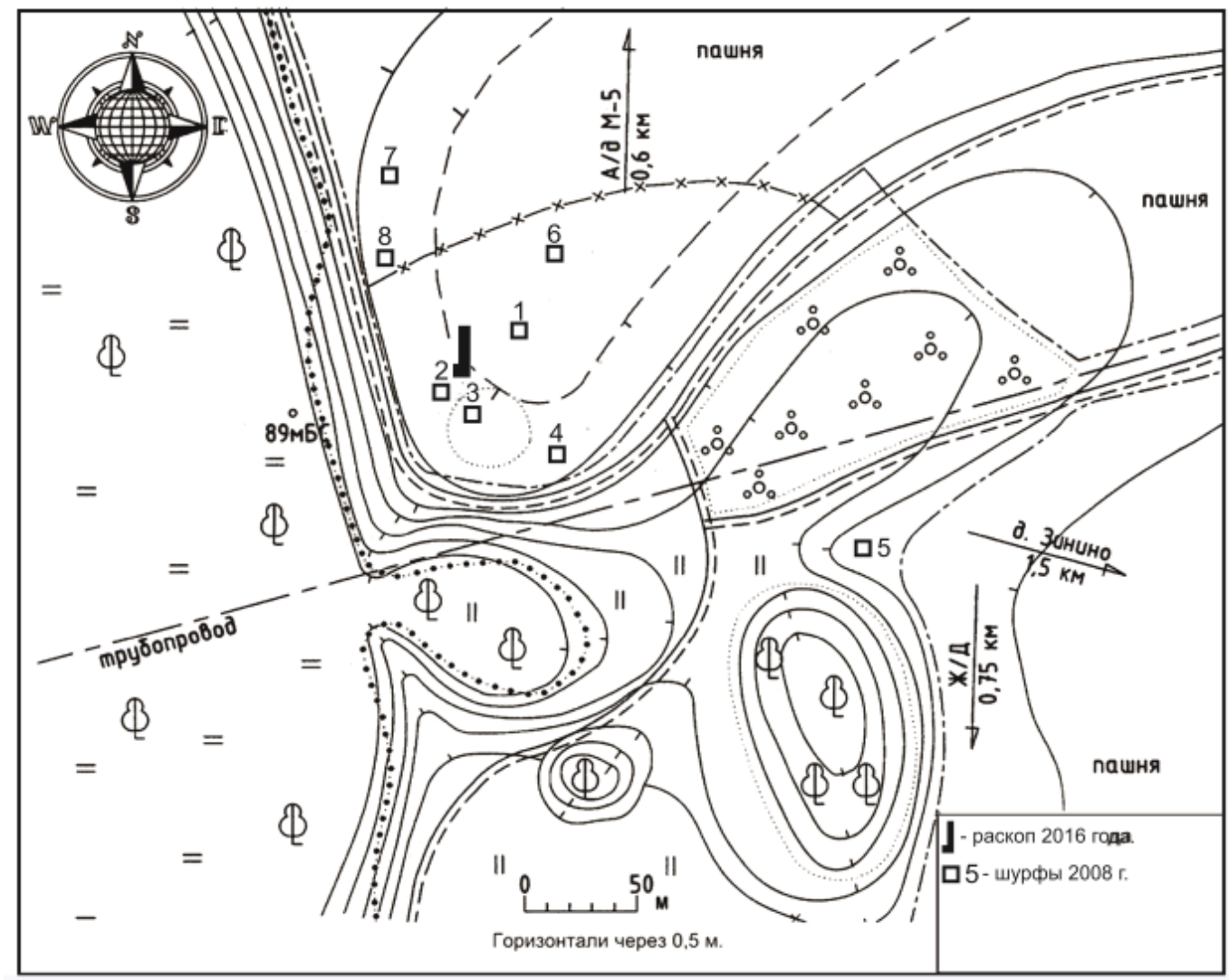

Рис. 1. Топографический план (основа Бахшиев, Савельев, 2013, с. 106 с дополнениями А.С. Проценко).

Fig. 1. Topographic plan (after Bakhshiev, Saveliev, 2013, p. 106, amended by A.S. Protsenko). 
Таблиия 1

Распределение керамики с разным составом примесей по горизонтам памятника

Table 1

Distribution of ceramics with different composition of impurities across the horizons of the site

\begin{tabular}{|c|c|c|c|c|}
\hline Место нахождения & Раковина & Песок & Раковина +песок & Итого \\
\hline Горизонт 1 & - & 179 & 26 & $205^{2}$ \\
\hline Горизонт 2 & 3 & 80 & 15 & $98^{3}$ \\
\hline Горизонт 3 & 2 & 46 & 4 & 52 \\
\hline
\end{tabular}
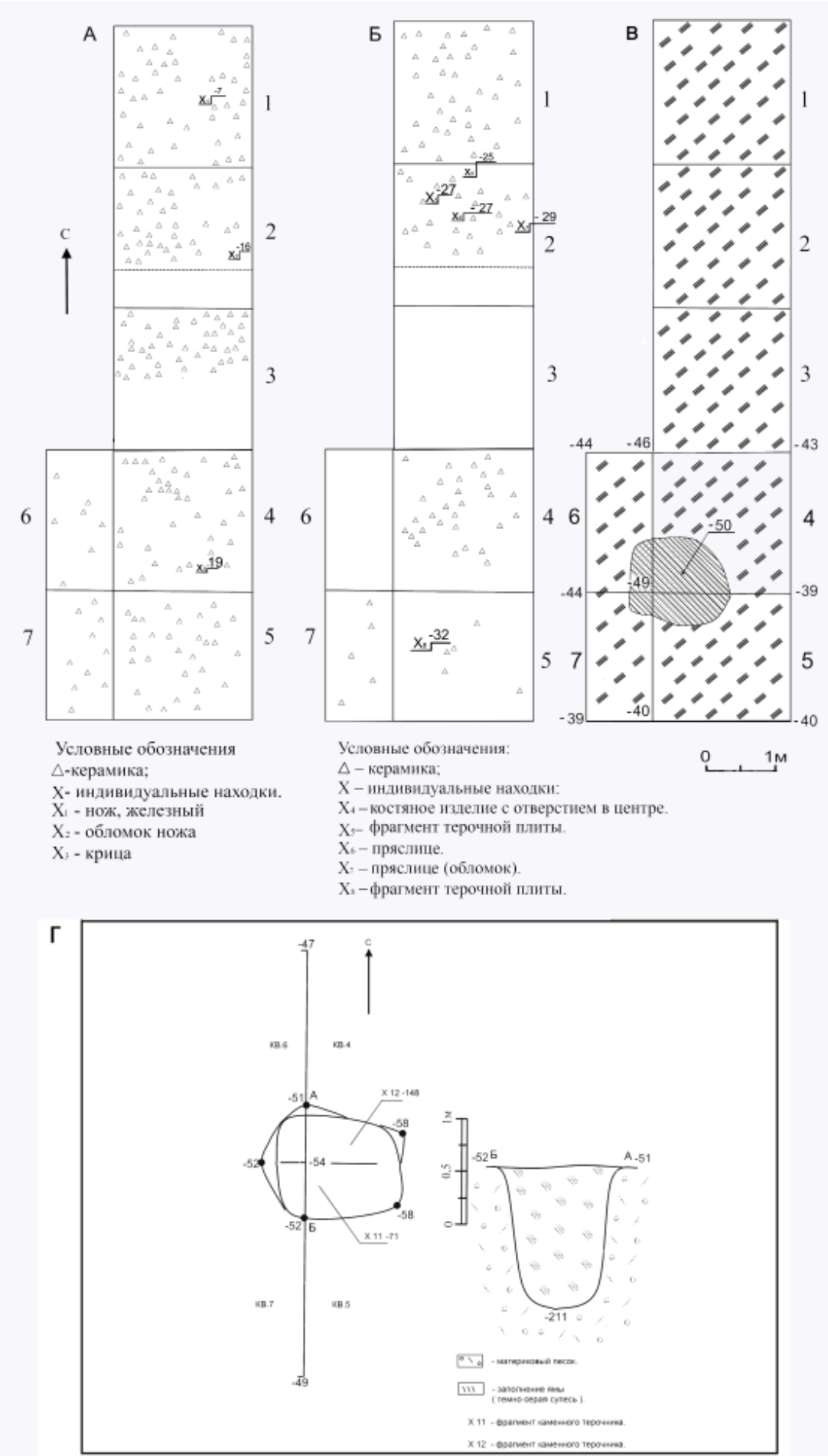

Рис. 2. Селище Зинино-1. Планиграфическая ситуация: А - гор. 1; Б - гор. 2; В - объект хозяйственного назначения, на уровне материка; Г - план и профиль объекта 1 (хозяйственной ямы).

Fig. 2. Zinino-1 ancient village. Planigraphic situation: A - horizon 1; B - horizon 2; B - utility structure at continent level; D - plan and profile of structure 1 (utility pit). 


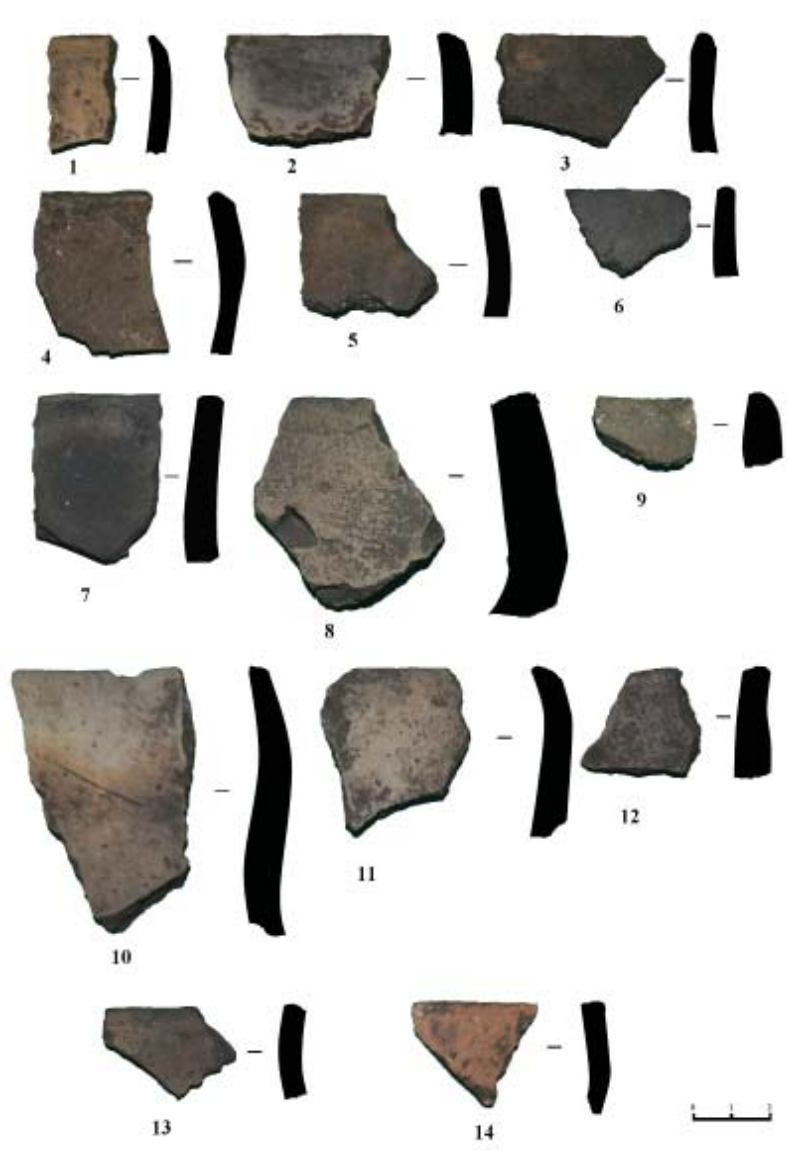

галась многолетней распашке). Стратиграфия всего раскопа однотипна: верхний слой представляет собой темно-серую гумусированную супесь мощностью $0,15-0,25 \mathrm{M}$, нижележащий слой представляет собой светло-серую гумусированную супесь мощностью $0,1-0,25$ м и материковый песок $0,05-0,15$ м.

Основная масса находок - фрагменты лепной керамики. Большинство находок сосредоточены в верхних горизонтах культурного слоя, не глубже 0,3 м. Общая глубина до материка составляет 0,4-0,5 м от современной поверхности. Всего в ходе исследований получено 426 артефактов, из которых $414-$ фрагменты лепной керамики: 367 стенок, 44 венчика, 3 придонные части.

Предыдущими исследователями установлено, что селище Зинино-1, скорее всего, являлось сезонной стоянкой (летником?) населения Акбердинского II городища (Бахшиев, Савельев, 2013, с. 114). В.В. Овсянниковым и Н.С. Савельевым был проведен анализ примесей к формовочной массе сосудов с данного городища, что позволило выделить хорошо фиксируемые четыре культурные группы: гафурийская (тальк, тальк-раковина), кара-абызская (раковина, раковина-органика, раковина-органика-шамот, раковинашамот), убаларская (песок, песок-шамот, песок-шамот-органика) и микс/смешанная
Рис. 3. Селище Зинино-1.

Фрагменты лепных сосудов. Гор. 1.

Fig. 3. Zinino-1 ancient village.

Fragments of molded vessels. Horizon 1.

(раковина-песок, песок-шамот-раковина, раковина-песок-органика, песок-шамот-раковина-органика) (Овсянников, Савельев, 2019, с. 204 ; Лясович, 2020 , с. 48 ).

Мы продолжили использовать данную методику и провели анализ керамики по выделенным культурным группам (табл. 1). Основная масса находок происходит из 1 горизонта - 210 фрагментов керамического материала (рис. 2: а). В нижележащих горизонтах количество керамики существенно снижается - на 2 горизонте обнаружено 99 фрагментов (рис. 2: б), на 3 горизонте - 52.

В целом, кара-абызская керамика селища Зинино-1 может быть охарактеризована как достаточно однородная (с присутствием убаларских и гафурийских традиций) (рис. $3,4)$. Большая часть керамики не орнаментирована $(96,2 \%)$. Орнамент на керамике чаще всего располагается на основании горла и верхней части плечика, вообще орнаментированных фрагментов небольшое количество (всего 14 фрагментов (3,8\%)): орнамент в виде круглых ямок встречен в 6 случаях (рис. 5: 7; 6: 7; 7: 12), ногтевые вдавления и насечки зафиксированы также в 5 случаях (рис. 7: 11), в двух случаях орнамент был в виде многорядного горизонтального зигзага и в одном случае орнамент представлен в виде резных дуг-гирлянд. В связи с небольшими размерами фрагментов керамического материала мы в своем исследовании намеренно опускаем вопрос о формах сосудов.

На втором горизонте был зафиксирован «гафурийский» венчик (с характерным массивным утолщением) с примесью талька, данный тип керамики был распространен на раннем этапе взаимодействия лесостепного постананьинского и степного раннепрохоровского населения (Савельев, 2010, с. 312-313; Савельев, 2011). По данному фрагменту удалось провести реконструкцию верхней части сосуда (рис. 4) и установить его диаметр $(\mathrm{d}=20 \mathrm{~cm})$.

Самая многочисленная группа керамики - убаларская, из общей массы уверенно выделяется по очень плотной фактуре и запесоченности теста, толщина стенок сосудов варьируется в пределах $0,3-0,5$ см (рис. 3,5 ). Часть сосудов при переходе от горла к плечику имеет уступчик. Найдены также три фрагмента плоских днищ (рис. 6: 1-3), т. е. часть 


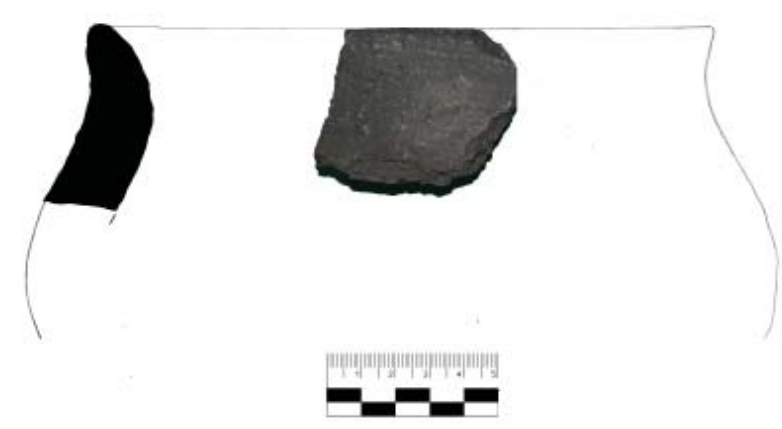

сосудов могла иметь уплощенное дно. Цвет поверхностей убаларских сосудов серый, темно-серый или светло-коричневый.

В ходе исследований был выявлен объект хозяйственного назначения, который зафиксирован в юго-западном углу кв. 4 на поверхности материка, в связи с этим были заложены дополнительные кв. 5 размерами $2 \times 2$ м и кв. 6 и 7 размерами $1 \times 2$ м (рис. $2:$ в, г). В результате удалось определить точные параметры Объекта, который имел размеры $1,55 \times 1,5 \mathrm{M}$, глубина от уровня материка составила 1,6 м. Стенки хозяйственной ямы были отвесными; форма конусовидная, стенки сужались к низу. Заполнение ямы представляло собой однородную темно-серую супесь. Вскрытие велось условными горизонтами (1-2; 3-4 и 5-6), выбор данной методики предполагал фиксацию напластований заполнения данного объекта. На 1-2 горизонте обнаружено 17 фрагментов керамики (2 венчика и 15 стенок), на 3-4 горизонте - 22 фрагмента керамики (19 стенок и 3 венчика) и на 5-6 условном горизонте - 10 фрагментов (3 венчика и 8 стенок) (рис. 6). В заполнении также найдено небольшое скопление глиняной обмазки (10 фрагментов), фрагменты костей животных. Из индивидуальных находок зафиксировано два фрагмента каменных терочных плит. Стратиграфическое залегание керамики показывает следующую картину: из всех фрагментов только два орнаментированы (круглой ямкой и насечками), которые были зафиксированы на 3-4 условном горизонте. Отметим, что из 50 фрагментов только 11 имеют примесь раковина+песок, в оставшейся керамике примесь песка в тесте. Таким образом, заполнение хозяйственной ямы свидетельствует о том, что она возникла и функционировала в

Рис. 5. Селище Зинино-1. Фрагменты лепных сосудов: 1-2 стенки - гор. 2; 3-4 венчики - гор. 3; 5-10 стенок- гор. 3.

Fig. 5. Zinino-1 ancient village. Fragments of molded vessels: $1-2$ walls - horizon $2 ; 3-4$ rims - horizon $3 ; 5-10$ walls - horizon 3 .
Рис. 4. Селище Зинино-1. Реконструкция верхней части сосуда (гафурийский тип). Гор. 2.

Fig. 4. Zinino-1 ancient village. Reconstruction of the upper portion of a vessel (Gafurian type). Horizon 2.

убаларское время (78\% керамики убаларского типа и $22 \%$ относится к так называемой смешанной/микс группе).

Индивидуальные находки немногочисленны: 4 терочника, 1 костяная заготовка для стрелы, 1 железный нож и 1 фрагмент железного ножа, 2 костяных изделия, 1 крица и 2 пряслица. Ниже приведено точное описание индивидуальных находок с раскопа:

1) Фрагмент терочной плиты. Местонахождение: кв. 5, гор. 2. Размеры: $12 \times 7$ см.

2) Фрагмент терочной плиты. Местонахождение: кв. 2, гор. 2. Размеры: $8 \times 5,5$ см.

3) Фрагмент терочной плиты. Местонахождение: объект 1 (хозяйственная яма), гор. 1-2. Размеры: $8 \times 7$ см.

4) Фрагмент терочной плиты. Местонахождение: объект 1 (хозяйственная яма), гор. 5-6. Размеры: $11 \times 7,5$ см.

5) Железный нож. Местонахождение: кв.1, гор. 1. Размеры: $9 \times 1,6$ см.

6) Костяная заготовка наконечника стрела. Местонахождение: кв.1, гор. 3. Размеры: $5,5 \times 1,5 \mathrm{~cm}$.

7) Фрагмент железного ножа (обломан). Местонахождение: кв. 2, гор. 1. Размеры: длина $4 \times 1 \mathrm{~cm}$.
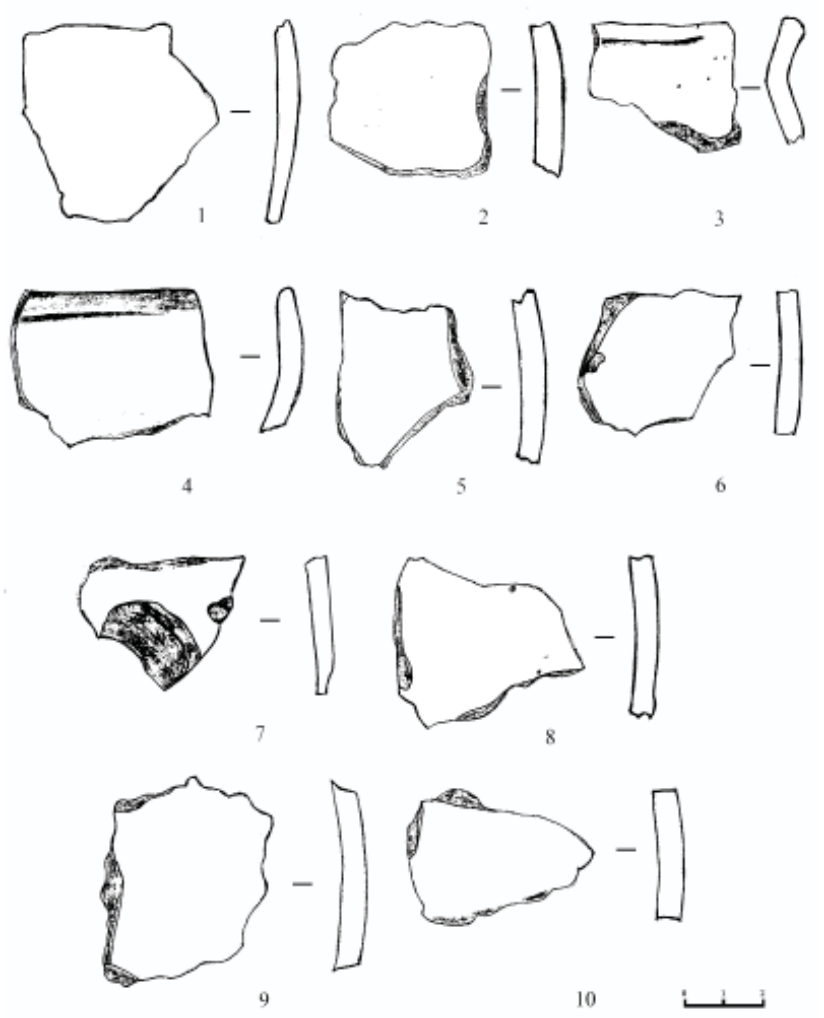
8) Костяное изделие с отверстием в центре (рис. 8: 4). Местонахождение: кв. 2, гор. 2. Размер: $5,5 \times 2 \mathrm{~cm}$.

9) Глиняное коническое пряслице (рис. 7: 1). Местонахождение: кв. 2, гор. 2. Диаметр $4,5 \mathrm{~cm}$.

10) Фрагмент глиняного конического пряслица (рис. 8: 2). Местонахождение: кв. 2, гор. 2. Диаметр 4,5 см.

11) Костяное изделие (по форме наконечника стрелы) (рис. 8: 3). Местонахождение: кв. 2, гор. 3. Размеры: 4,7×1,5 см.

12) Крица (Рыхлая губчатая пропитанная шлаком железная масса). Местонахождение: кв. 4, гор. 1. Размеры: 7×5,5 см.

Фрагменты терочников были исследованы на предмет выявления спор и пыльцы растений, для выяснения их функционального назначения ${ }^{4}$. При лабораторной обработке проб использовалась стандартная методика мацерации осадочных пород (Гричук, Заклинская, 1948, с. 127-136), включающая ряд дополнений. В результате микроскопиче- ского изучения полученного мацерата пыльца и споры в составе образцов обнаружены не были. Поскольку терочники использовались для растирания и толчения различных материалов, отсутствие находок растительных остатков позволяет сделать вывод, что, вероятнее всего, они не были задействованы при приготовлении пищи. Однако это лишь предварительное заключение, во-первых, речь идет лишь об изученных образцах, во-вторых, более эффективным может оказаться выявление зерен крахмала. Можно предположить, что терочники, к примеру, могли использоваться для дробления и перетирания раковин, которые в размытом виде добавлялись в глину при производстве керамических изделий (Проценко, Сатаев, 2016, с. 130-131).

Остатки животных, происходящие из раскопок селища Зинино-1, представлены исключительно костями млекопитающих (121 экз.), принадлежащих 5 домашним и 2 диким видам (табл. 2). Кости животных сильно раздроблены и являются, преимущественно,

Видовой и количественный состав костных остатков животных

Таблийа 2 из раскопок селища Зинино-1*

Table 2

Species and quantitative composition of the bone remains of animals from the excavations of Zinino-1 ancient village

\begin{tabular}{|c|c|c|c|c|c|c|}
\hline \multirow[t]{2}{*}{ Виды } & \multicolumn{3}{|c|}{ Горизонты } & \multicolumn{3}{|c|}{ Хозяйственная яма } \\
\hline & $\mathrm{I}$ & II & III & гор. I-II & гор. III-IV & гор. IV-V \\
\hline \multicolumn{7}{|c|}{ Домашние млекопитающие } \\
\hline $\begin{array}{c}\text { KPC** } \\
\text { Bos taurus }\end{array}$ & 15 & 1 & 5 & 1 & & 1 \\
\hline $\mathrm{MPC} * * *$ & 5 & 5 & 5 & 3 & & 1 \\
\hline $\begin{array}{c}\text { Овца } \\
\text { Ovis aries }\end{array}$ & - & - & 1 & - & - & - \\
\hline $\begin{array}{c}\text { Свинья } \\
\text { Sus scrofa domesticus }\end{array}$ & 2 & - & 1 & - & 1 & - \\
\hline $\begin{array}{c}\text { Лошадь } \\
\text { Equus caballus }\end{array}$ & 8 & 2 & 2 & & 4 & 1 \\
\hline $\begin{array}{c}\text { Собака } \\
\text { Canis familiaris }\end{array}$ & 4 & - & - & 1 & - & - \\
\hline \multicolumn{7}{|c|}{ Дикие млекопитающие } \\
\hline $\begin{array}{c}\text { Медведь бурый } \\
\text { Ursus arctos }\end{array}$ & - & - & 2 & - & - & - \\
\hline $\begin{array}{c}\text { Полевка } \\
\text { Microtus sp. }\end{array}$ & 1 & - & - & - & - & - \\
\hline Определимые & 35 & 8 & 16 & 5 & 5 & 3 \\
\hline Неопределимые & 22 & 6 & 8 & 8 & 4 & 1 \\
\hline Всего & 57 & 14 & 24 & 13 & 9 & 4 \\
\hline
\end{tabular}

* - подъемный материал не учитывался

* КРС - крупный рогатый скот

*** MPC - мелкий рогатый скот, в данном случае остатки животных, не определимые точнее до рода (Capra hircus + Ovis aries) 


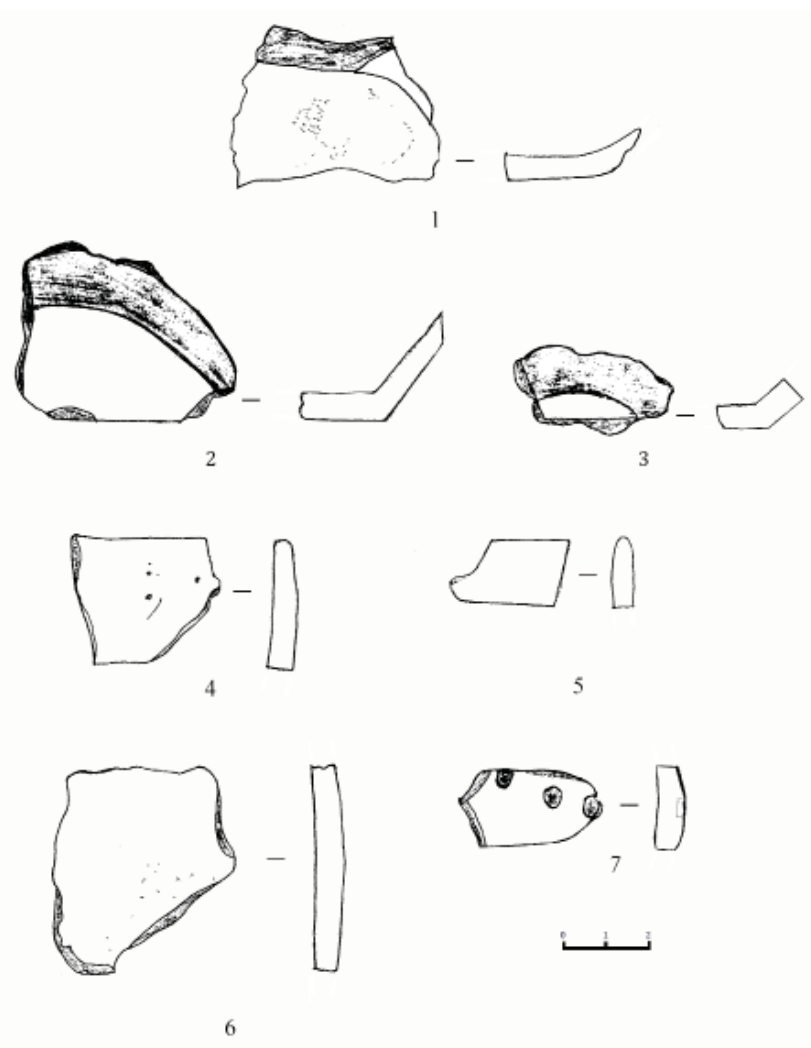

кухонными отходами. Возможно, что часть фрагментов образовалось уже при вторичном раскалывании (после разделки туши и пищевой утилизации мяса), в процессе изготовления костяных орудий (в материале обнаружена заготовка наконечника стрелы). Из общего объема костей млекопитающих идентифицировано лишь $59,5 \%$ (72 кости).

По площади и глубине раскопа кости распределены неравномерно (табл. 3). Только в 1 горизонте остатки животных встречены во всех квадратах. В целом следует отметить невысокую концентрацию костей животных в культурном слое.

Из общего количества костей видов, традиционно являющихся источником мясной продукции (крупный и мелкий рогатый скот, свинья, лошадь), на крупный рогатый скот приходится $35,9 \%$, мелкий рогатый скот $31,3 \%$, свинью $6,3 \%$ и лошадь $26,5 \%$. Хотя изученная выборка не является репрезентативной, вероятнее всего, в той или иной степени эти значения отражают вклад отдельных видов в мясной рацион древнего населения. В пользу такого заключения может свидетельствовать присутствие в археозоологичесом материале костей 4 видов, разводившихся в хозяйственных целях (конечно, животных использовали не только на мясо, но об этом нам судить сложно). Заметим, что небольшие по объему выборки часто включают кости одного или преимущественно одного вида.
Рис. 6. Селище Зинино-1. Фрагменты лепных сосудов:1 - придонная часть, гор. 1; 2-3 - придонная часть, гор. 3; 4-5 - венчики, гор. 3; 6-7 - стенки, гор. 3.

Fig. 6. Zinino-1 ancient village. Fragments of molded vessels: 1 - bottom part, horizon $1 ; 2-3$ - bottom part, horizon 3; 4-5-rims, horizon 3; 6-7 - walls, horizon 3 .

Следует добавить, что условный перевод количества костей на объем потребляемой мясной продукции с учетом весовых различий разных видов дает следующие значения: на крупный рогатый скот приходится 53,5\% потребляемого мяса, на лошадь - 36,4\%, на мелкий рогатый скот $-7,8 \%$, свинью $-2,3 \%$. Здесь мы использовали кратность туш животных, предложенную Е.Е. Антипиной (Антипина, 2008, с. 71). Таким образом, крупный рогатый скот лидирует и в этом случае.

Малочисленность материала и его сохранность почти не позволяют оценить возраст забоя скота и его экстерьерные характеристики. Можно лишь отметить, что кости КРС и МРС происходят от взрослых животных, а кости лошади, преимущественно, от молодых особей (встречены нестертые резцы и фрагменты непрорезавшихся зубов).

В целом можно говорить, что основой мясного рациона жителей селища являлась говядина и конина (хотя эти выводы лишь предварительные). Отметим, что аналогичные результаты были получены нами по материалам с городища Кара-Абыз, где первое место в питании населения по объему также занимала говядина, второе - конина, и лишь третье - мелкий рогатый скот, хотя различия между этими видами получаются не такими значительными (Проценко, Сатаев, 2016, с. 129).

В связи с тем, что наиболее массовый археологический материал представлен фрагментами лепной керамики, остановимся на его интерпретации. В результате анализа примесей к формовочной массе сосудов рассмотрены четыре культурные группы, по которым распределена керамика. Самая малочисленная - гафурийская $(0,3 \%)$, к данной группе мы можем уверенно отнести только один венчик с примесью талька; следующая - кара-абызская (1,4\%), с примесью раковины в тесте; микс/смешанная (12,5\%) - с примесью раковины и песка. Предыдущими исследователями селища было отмечено, что среди убаларской серии присутствуют фрагменты с примесью раковины в тесте, а среди караабызской - фрагменты с дополнительной примесью мелкого песка. Данный факт, по мнению авторов, свидетельствует о наличии 

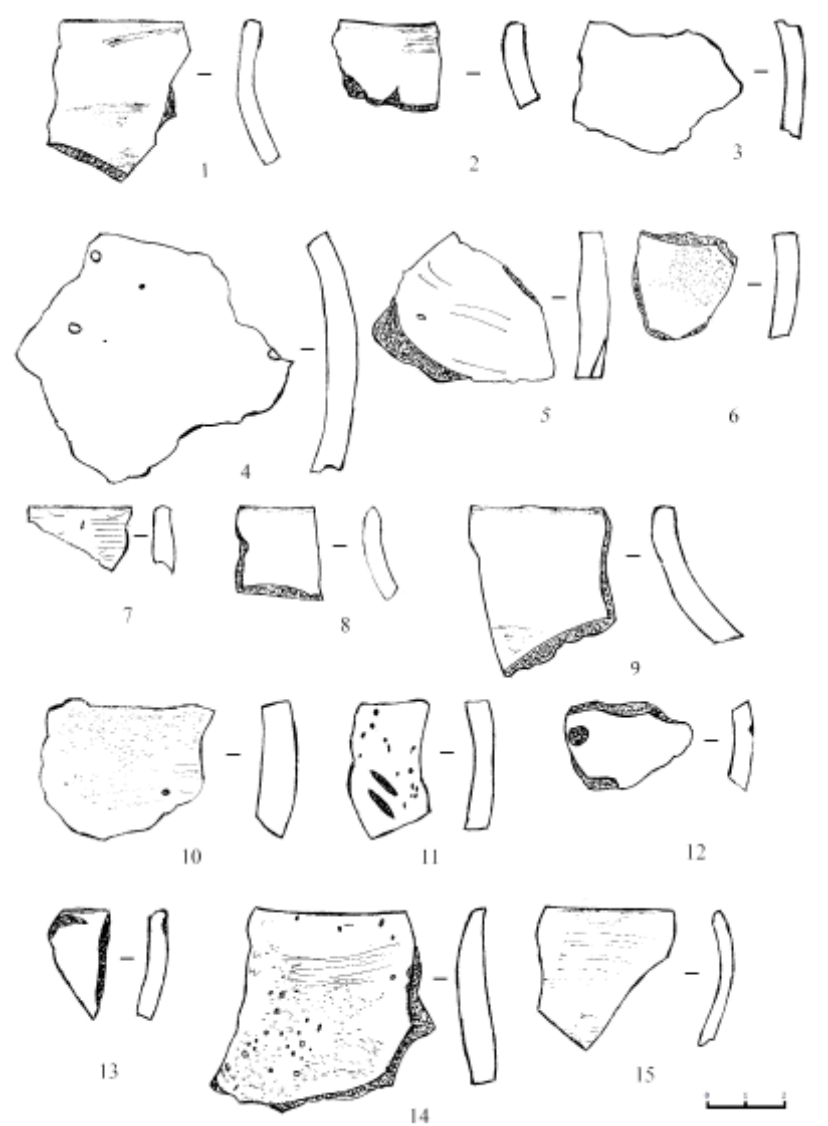

метисной кара-абызско-убаларской керамики, при этом смешение традиций прослеживается как на уровне форм сосудов, так и на уровне примесей. При этом можно констатировать, что в «чистом» виде кара-абызский, гафурийский и убаларский керамические комплексы настолько различны, что любые их комбинации могут восприниматься только как те или иные варианты механического смешения, свидетельствующие об идущем процессе постепенной ассимиляции (Бахшиев, Савельев, 2013, с. 112).

Самая представительная - убаларская культурная группа (85,8\%), с примесью песка в тесте. Как справедливо отмечает Н.С. Савельев, интерес к убаларским памятникам, возникший с самого момента их открытия в конце 1950-х годов, даже к настоящему времени так и не перерос в предмет отдельного исследования, а сам «убаларский тип» так и не получил однозначной интерпретации (Савельев, 2017, с. 20). Данный пробел в понимании не только возникновения, но и сложения и

Рис. 8. Селище Зинино-1. Индивидуальные находки: 1-2 - глиняные пряслица, гор. $2 ; 3$ - костяное изделие (по форме наконечника стрелы), гор. 3; 4 - костяное изделие с отверстием в центре, гор. 2.

Fig. 8. Zinino-1 ancient village. Individual finds: 1-2 - clay spinning wheel, horizon $2 ; 3$ - bone item (with an arrowhead shape), horizon $3 ; 4-$ bone item with a hole in the center, horizon 2.
Рис. 7. Селище Зинино-1. Фрагменты лепных сосудов, заполнение хозяйственной ямы: 1-2 -венчики, гор. 1-2; 3-6 - стенки, гор. 1-2; 7-9 - венчики, гор.3-4; 10-12 стенки, гор. 3-4; 13-15 - венчики, гор. 5-6.

Fig. 7. Zinino-1 ancient village. Fragments of molded vessels, filling material of the utility pit: $1-2-$ rims, horizon $1-2 ; 3-6-$ walls, horizon $1-2 ; 7-9-$ rims, horizon $3-4 ; 10-12$ - walls, horizon $3-4 ; 13-15$ - rims, horizon 5-6.

развития вышеотмеченного культурного типа рассмотрен в работе Н.С. Савельева. Автором проведена скрупулезная источниковедческая работа, которая позволила ответить на накопившиеся вопросы и подвести итог проведенным исследованиям (Савельев, 2017).

Полученные материалы с селища Зинино-1 дополняют ранее сделанные выводы. В настоящее время мы можем уже достаточно уверенно говорить, что кара-абызские и кара-абызско-гафурийские материалы указывают на границу между южным и северным локальными вариантами кара-абызской культуры, проходившую по приустьевой части р. Уфы. Расширение убаларского варианта караабызской культуры на север, произошедшее примерно во II в. до н. э., привело к постепенному замещению кара-абызских и гафурийских керамических традиций на убаларские (Бахшиев, Савельев, 2013, с. 115). По полученным материалам, замещение керамических традиций, возможно, произошло если не одномоментно, то значительно быстрее, чем это представлялось ранее. Для подтвержде-
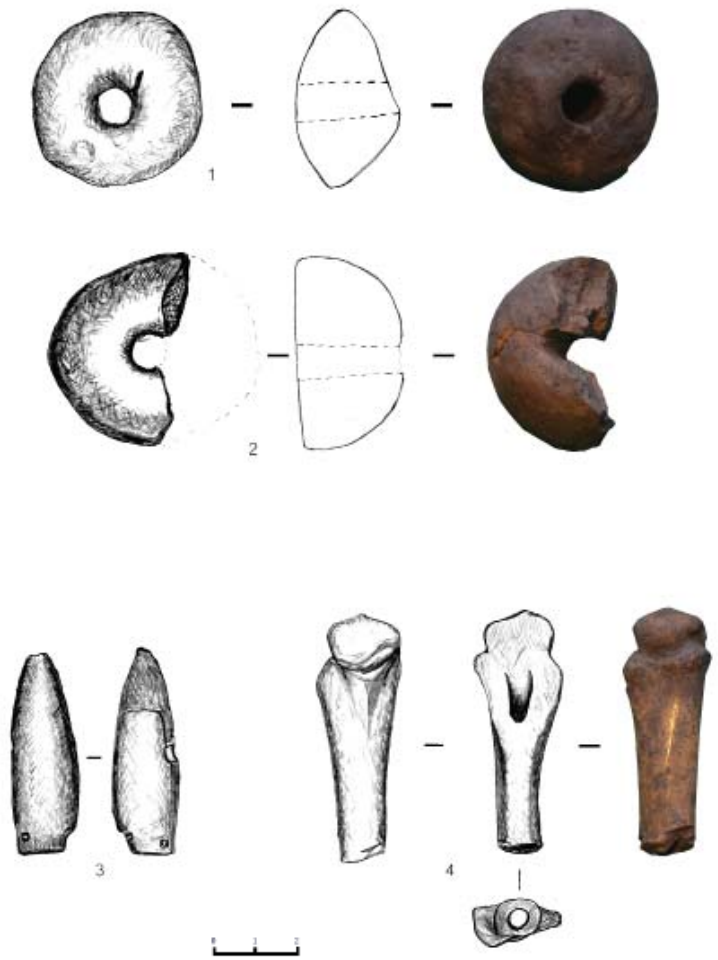
Распределение костных остатков животных по горизонтам и квадратам раскопа селища Зинино-1

Distribution of animal bone remains across the horizons and sections of the excavation site of Zinino-1 ancient village

Горизонт I

\begin{tabular}{|c|c|c|c|c|c|c|}
\hline \multirow{2}{*}{ Виды } & \multicolumn{6}{|c|}{ Квадраты } \\
\cline { 2 - 7 } & I & II & III & IV & V & VI \\
\hline КРС & & 4 & 3 & 2 & 6 & \\
\hline МРС & 1 & & 1 & 2 & & 1 \\
\hline Свинья & & & & & 2 & \\
\hline Лошадь & 1 & & 1 & 2 & 3 & 1 \\
\hline Собака & 2 & & 2 & & & \\
\hline Грызуны & & & & & 1 & \\
\hline Неопределимые & 9 & 4 & 2 & 4 & 3 & \\
\hline
\end{tabular}

\begin{tabular}{|c|c|c|c|c|c|c|c|}
\hline \multirow[t]{3}{*}{ Виды } & \multicolumn{2}{|c|}{ Горизонт II } & \multicolumn{5}{|c|}{ Горизонт III } \\
\hline & \multicolumn{7}{|c|}{ Квадраты } \\
\hline & I & $\mathrm{V}$ & $\mathrm{I}$ & II & $\mathrm{V}$ & Vскопл.керам. & Бровка \\
\hline КРC & & 1 & & 4 & & & 1 \\
\hline MPC & 2 & 3 & 1 & & 2 & 1 & 1 \\
\hline Овца & & & & & & 1 & \\
\hline Свинья & & & 1 & & & & \\
\hline Лошадь & 1 & 1 & 2 & & & & \\
\hline Медведь & & & & 1 & & & 1 \\
\hline Неопределимые & 5 & 1 & & 3 & 3 & 2 & \\
\hline
\end{tabular}

\begin{tabular}{|c|c|c|c|c|}
\hline \multicolumn{5}{|c|}{ Обособленные выборки } \\
\hline Виды & $\begin{array}{c}\text { Хоз. яма } \\
\text { гор. I-II }\end{array}$ & $\begin{array}{c}\text { Хоз. яма } \\
\text { гор. III-IV }\end{array}$ & $\begin{array}{c}\text { Хоз. яма } \\
\text { гор. IV-V }\end{array}$ & $\begin{array}{c}\text { Подъемный } \\
\text { материал }\end{array}$ \\
\hline КРС & 1 & & 1 & 2 \\
\hline МРС & 3 & & 1 & \\
\hline Свинья & & 1 & 1 & \\
\hline Лошадь & & 4 & & \\
\hline Собака & 1 & 4 & 1 & \\
\hline Неопределимые & 8 & 4 & & \\
\hline
\end{tabular}

ния данного тезиса пока, однако, недостаточно фактов.

Предыдущими исследователями было выдвинуто предположение, что с приходом убаларского населения происходит трансформация хозяйства (Бахшиев, Савельев, 2013, c. 115). Данный тезис, по материалам 2016 г., не находит дополнительной аргументации. По нашему мнению, убаларское население существенно не повлияло как на изменение хозяйственного уклада, так и на переход от оседлого скотоводства к полукочевому. По крайней мере, археологического материала на данный момент недостаточно для подобного рода выводов.

На сегодняшний момент идет накопление и первичный анализ археологических, палеоботанических (Овсянников, 2018; Проценко, Курманов, 2019; Курманов и др., 2019; и др.) и палеозоологических (Проценко, Сатаев, 2016; Воробьева, 2017) материалов по поселенческим памятникам кара-абызской культуры, что в дальнейшем дает исследователям реальную возможность на качественно новой основе проанализировать особенности хозяйственной деятельности древнего населения Южного Приуралья в эпоху раннего железного века.

Таким образом, материалы селища Зинино-1 в целом подтверждают ранее выдвинутые исследователями выводы и общую датировку памятника в пределах II в. до н. э. - II в. н. э. (Овсянников и др., 2015, с. 108; Савельев, 2017 , с. 33). В свою очередь, необходимо отметить, что сложные процессы, проходившие на рубеже эр внутри кара-абызской культуры, существенно не повлияли на хозяйственнокультурный тип. 


\section{Примечания:}

${ }^{1}$ Единственным моментом, упущенным исследователем, является отсутствие ссылки на работу И.М. Бабина, который в 2015 г. на водоразделе р. Белая и р. Юрмаш, первым проводил разведку широкого оврага между н.п. Нагаево и Акбердино и выявил новый объект археологического наследия - Акбердино-8 селище (Бабин, 2015).

${ }^{2}$ На месте заложения раскопа был собран подъемный материал в количестве пяти фрагментов (2 венчика и 3 стенки, неорнаментированные).

${ }^{3}$ В кв. 1 на гор.2 был найден один фрагмент «гафурийского» венчика с примесью талька в тесте.

${ }^{4}$ Исследование проведено Курмановым Равилем Гадельевичем, к.б.н., научным сотрудником Института геологии Уфимского федерального исследовательского центра РАН.

\section{ЛИТЕРАТУРА}

Антипина E.E. Состав древнего стада домашних животных: логические аппроксимации // OPUS: Междисциплинарные исследования в археологии. Вып. 6. / Ред. А.П. Бужилова. М.: Изд-во «Параллели», 2008. С. 67-85.

Бабин И.М. Научный отчет о проведении археологической разведки в бассейне р. Юрмаш и на водораздельной территории р. Белая, р. Юрмаш в Иглинском районе Республики Башкортостан в 2015 году по Открытому листу №1372 от 18.08.2015 г. / Архив Лаборатории археологического источниковедения и историографии БГПУ им. М. Акмуллы.

Бахшиев И.И., Савельев Н.С. К изучению некоторых вопросов этнокультурной динамики и хозяйства населения лесостепи Южного Приуралья эпохи раннего железа (по материалам селища Зинино-1) // УАВ. 2013. № 13. С. 104-115.

Воробьева С.Л. Хозяйство носителей кара-абызской археологической культуры эпохи раннего железа (по материалам поселенческих памятников IV-I веков до нашей эры // Этнические взаимодействия на Южном Урале. Сарматы и их окружение. Материалы VII Всероссийской (с международным участием) научной конференции / Отв. ред. А.Д. Таиров. Челябинск: ОГБУК «Государственный исторический музей Южного Урала», 2017. С. 31-37.

Гричук В.П., Заклинская Е.Д. Анализ ископаемых пыльцы и спор и его применение в палеогеографии. М.: Географгиз, 1948. 224 с.

Курманов Р.Г., Овсянников В.В., Савельев Н.С., Галеев Р.И. Реконструкция растительности и климата Южного Предуралья в суббореале и субатлантике (по материалам памятников кара-абызской культуры) // Геологический вестник. 2019. № 1. С. 35-44.

Лясович В.И. Сезонная система использования территории лесостепного Приуралья населением рубежа эр // УАВ. 2020 Вып. 20. С. 44-52.

Овсянников B.B. Естественнонаучные исследования культурного слоя поселений Прибелья эпохи раннего железа // XXI Уральское археологическое совещание, посвященное 85-летию со дня рождения Г.И. Матвеевой и 70-летию со дня рождения И.Б. Васильева. Материалы Всероссийской научной конференции с международным участием / Ред. А.А. Выборнов. Самара: СГСПУ, 2018. С. 232-234.

Овсянников В.В., Каюмов И.Х., Бабин И.М. Новые материалы с поселений кара-абызской культуры // УАВ. 2015. Вып. 15. С. 85-110.

Овсянников В.В., Савельев Н.С. Воинское святилище на Акбердинском II городище // Археология Евразийских степей. 2019. №2. С. 201-226.

Проценко А.С., Курманов Р.Г. Археолого-палинологические исследования культурного слоя городища Кара-Абыз // Вестник Ан РБ. 2019. Т. 33. № 4 (96). С. 62-71.

Проченко А.C., Сатаев Р.М. К вопросу об основах жизнеобеспечения носителей кара-абызской культуры // Вестник Томского государственного университета. История. 2016. №6 (44). С. 125-133.

Савельев Н.С. Керамические импорты кара-абызской культуры: их происхождение, контекст и датирующие возможности // Археология и палеоантропология евразийских степей и сопредельных территорий / МИАР. Вып. 13 / Отв. ред. М.М. Герасимова, В.Ю. Малашев, М.Г. Мошкова. М.: Таус, 2010. C. 295-318.

Савельев Н.С. Гафурийский керамический комплекс эпохи раннегожелеза с Биктимировского городища // РА. 2011. №2. С.56-66.

Савельев Н.С. О происхождении убаларского культурного типа в лесостепи Южного Приуралья // УАВ. 2017. №17. С. 18-38.

\section{Информация об авторах:}

Проценко Антон Сергеевич, заведующий отделом археологии, Государственное бюджетное учреждение Республиканский историко-культурный музей-заповедник «Древняя Уфа» (г. Уфа, Россия); anton.procenko@mail.ru

Сатаев Роберт Мидхатович, кандидат биологических наук, научный сотрудник временного творческого коллектива, Институт этнологии и антропологии им. Н.Н. Миклухо-Маклая РАН (г. Москва, Россия); rob-sataev@mail.ru 


\section{REFERENCES}

Antipina, E. E. 2008. In Buzhilova, A. P. (ed.). OPUS: Mezhdistsiplinarnye issledovaniia v arkheologii (OPUS: Interdisciplinary Investigation in Archaeology) 6. Moscow: Institute of Archaeology RAS (6), 67-85 (in Russian).

Babin, I. M. 2015. Nauchnyi otchet o provedenii arkheologicheskoi razvedki v basseine r. Yurmash i na vodorazdelnoi territorii $r$. Belaia, $r$. Yurmash v Iglinskom raione Respublike Bashkortostan v 2015 godu po Otkrytomu listu №1372 ot 18.08.2015 g. (Scientific Report on the Archaeological Exploration in the Basin of the Yurmash River and the Watershed Area of the Belaya River, Yurmash River in the Iglinsky District of the Republic of Bashkortostan in 2015 on the Basis of the Open Sheet No. 1372 dated August 18, 2015). Archive of the Laboratory of Archaeological Source Study and Historiography of the Bashkir State Pedagogical University named after M. Akmullah) (in Russian).

Bakhshiev, I. I., Savel'ev, N. S. 2013. In Ufimskii arkheologicheskii vestnik (Ufa Archaeological Herald) (13), 104-115 (in Russian).

Vorobeva, S. L. 2017. In Tairov, A. D. (ed.). Etnicheskie vzaimodeistviia na Iuzhnom Urale (Ethnic Interactions in Southern Ural) VII. Chelyabinsk: State Museum of the South Ural History, 31-37. (in Russian).

Grichuk, V. P., Zaklinskaya, E. D. 1948. Analiz iskopaemykh pyl'tsy i spor i ego primenenie v paleogeografii (Analysis of Fossil Pollen and Spores and its Application in Paleogeography). Moscow: "Geografgiz" Publ. (in Russian).

Kurmanov, R. G., Ovsyannikov, V. V., Savel'ev, N. S., Galeev, R. I. 2019. In Geologicheskii vestnik (Geological Bulletin) (1), 35-44 (in Russian).

Ovsyanikov, V. V., Kayumov, I. Kh., Babin, I. M 2015. In Ufimskii arkheologicheskii vestnik (Ufa Archaeological Herald) (15), 85-110 (in Russian).

Ovsyanikov, V. V., Kayumov, I. Kh., Babin, I. M 2015. In Ufimskii arkheologicheskii vestnik (Ufa Archaeological Herald) (15), 85-110 (in Russian).

Ovsyanikov, V. V. 2018. In Vybornov, A. A. (ed.). XXI Ural'skoe arkheologicheskoe soveshchanie (21 $1^{\text {th }}$ Urals Archaeological Congress)). Samara: "Samara State University of Social Sciences and Education", "Porto-Print" Publ., 232-234 (in Russian).

Ovsyannikov, V. V., Savel'ev, N. S. 2019. In Arkheologiia Evraziiskikh stepei (Archaeology of Eurasian Steppes) 2, 201-226 (in Russian).

Protsenko, A. S., Sataev, R. M. 2016. In Vestnik Tomskogo Gosudarstvennogo universiteta. Istoriia (Bulletin of the Tomsk State University: History) 44 (6), 125-133 (in Russian).

Protsenko, A. S., Kurmanov, R. G. 2019. In Vestnik Akademii nauk Respubliki Bashkortostan (The Herald of the ASRB). Vol. 33.96 (4), 62-71 (in Russian).

Savel'ev, N. S. 2010. In Gerasimova, M. M., Malashev, V. Yu., Moshkova, M. G. (eds.). Arkheologiia i paleoantropologiia evraziiskikh stepei i sopredel'nykh territorii (Archaeology and Paleoanthropology of Eurasian Steppes and Adjacent Territories). Series: Materialy i issledovaniia po arkheologii Rossii (Materials and Studies in the Russian Archaeology) 13. Moscow: "Taus" Publ., 295-318 (in Russian).

Savel'ev, N. S. 2011. In Rossiiskaia Arkheologiia (Russian Archaeology) (2), 56-66 (in Russian).

Savel'ev, N. S. 2017. In Ufimskii arkheologicheskii vestnik (Ufa Archaeological Herald) (17), 18-38 (in Russian).

\section{About the Authors:}

Protsenko Anton S., Head of the Department of Archeology, State Budgetary Institution Republican Historical and Cultural Museum-Reserve "Ancient Ufa".Mustai Karim St., 45, Ufa, 450077, Republic of Baskortostan, Russian Federation; anton.procenko@mail.ru

Sataev Robert M. Candidate of Biological Sciences. N.N. Miklukho-Maklai Institute of Ethnology and Anthropology, Russian Academy of Sciences. Leninsky Ave., 32a, Moscow, 119334, Russian Federation; robsataev@mail.ru.

Статья поступила в журнал 01.02.2021 г. Статья принята к публикации 01.02.2021 г. Авторы внесли равноценный вклад в работу. 